\title{
Laik ve Otoriterlerin Hükümetlerine Karşı 'Müsbet Hareket' (Sivil İtaatsizlik) ve Dindar Demokratların Hükümetlerine Destek
}

Prof. Dr. Bünyamin DURAN

Celal Bayar Üniversitesi İktisadi ve İdari Bilimler Fakültesi

$\ddot{O} z$

Laik otoriter hükümetler genel olarak dini kültüre yıkıcı ve devrimci darbeler vurmas1 ve özel olarak kendisi ve talebelerini sürekli baskı ve zulüm altında bulundurmasına rağmen Bediüzzaman Said Nursi hiçbir zaman şiddete başvurmamış ve müspet hareket etmekten vazgeçmemiştir. Yazdığı kitaplar ve yüz binleri bulan izleyenleriyle hep toplumsal huzur ve barışın güvencesi olmaya çalışmıştır. 'Dindar Demokratlar'ın kurduğu hükümetlere karşı ise bir taraftan müspet hareket etmeye devam ederken diğer taraftan onların iktidarda kalması için gayret göstermiştir. Öte yandan Nusi, 'Dindar Demokratlar'ın hükümetlerinden beklentisini de sınırlı düzeyde tutmuş, onların hayırlı işlere müsamaha göstermesini desteklenmeleri için yeterli görmüştür. Çünkü o gerçekçi biri olarak, neredeyse tüm sivil ve askeri bürokratik yapının saldırgan seküler kesimlerin tekelinde olduğunu hiç göz ardı etmemiştir.

Anahtar Kavramlar: Müspet hareket, direnme hakkı, devrimci ve 1slahçı yaklaşım, laik otoriter hükümet, dindar demokratlar

\section{Civil Disobedience Against the Governments of Secular and Authoritarians and Support to the Governments of Pious Democrats}

\begin{abstract}
Nursi never used violence against governments which implemented radical secular and injustice policies. He and his followers are in the side of social and political cohesion and solidarity in spite of very in human governmental violence against the religious peoples and the religious heritage. Nursi's approach against 'pious democrat's government was very supportive and enthusiastic. His expectation from democratic government however was very minimal. As a relistperson, Nursi has a conscience that the democratic government's possibility to realize the ideal policies is nearly impossible due to political and social environments. He knows that nearly all bureaucratic structures are in the monopoly of the aggressive secular classes.
\end{abstract}

Key Words: Positive attitude, secular authoritarian government, pious democrats, Said Nursi, civil disobedience, rebellion, violence 


\section{Giriş}

Bu çalışmada ilk olarak Bediüzzaman Said Nursi'nin laik otoriter hükümetlere karşı siyasi tutumu ele alınacak ve daha sonra kendisinin 'Dindar Demokratlar' dediği kesimlerin kurduğu hükümetlere karşı tavır incelenecektir. Çalışma esnasında siyasi literatürde önemli bir konu olan 'direnme hakkı' ve çeşitlerine kısaca değinilecek, Nursi'nin 'direnme hakkı' çerçevesinde aldığı pozisyon ve nihayetinde de Nursi'nin 'Dindar Demokratlar' dediği, siyasî dilimize 'Ahrarlar' olarak giren kesimin özellikleri, Nursi’nin onların kurduğu hükümetlerden beklediği politikaların neler olduğu gibi konular Nursi'nin eserlerine dayanılarak belirlenmeye çalışılacaktır. Bu çerçevede Nursi izleyicilerinin Nursi sonrası dönemde siyasi tutum belirlerken hangi kriterleri esas aldıkları da ortaya konulmuş olacaktır.

\section{Genel Olarak 'Direnme Hakkı'}

Tarihte çok sık görüldüğü gibi zalim, baskıcı ve dikta eğilimli bir iktidar insan hak ve hürriyetlerini ayaklar altına alıp, bunlarla ilgili müesseseleri sistemli bir şekilde işlemez hâle getirebilir. Yasaların koyduğu yetki sınırlarını aşar ve kamu hürriyetlerini alabildiğine daraltarak bir baskı rejimi kurabilir. Aynı şekilde belli bir ideoloji ve doktrini toplumun fertlerine zorla dayatabilir. Hatta toplum fertlerini açık veya örtülü bir şekilde din değiştirmeye zorlayabilir. Bu takdirde fertlerin ilgili otoriter yönetime karşı tavrı ne olmalıdır? Fertler böyle bir baskı rejimine boyun mu eğmeli ya da şiddeti de kullanarak karşı mı koymalıdır? Bu iki tutum arasında başka bir orta yol yok mudur?

$\mathrm{Bu}$ sorular bizi "baskıya karşı direnme" sorununa götürür. Baskıya karşı direnme temel hak ve hürriyetleri korumak için fert ve grupların bazı karşı-araçlar geliştirmelerini öngörür. Bu karşı- araçların derece ve şiddeti basit ve etkisiz muhalefetten zor ve kuvvet kullanmaya kadar farklılaşır. Çeşitli yazarlar direnmenin çeşitli şekilleri üzerinde durmuş ve belli bir tasnif yapmaya çalışmışlardır. Bu tasniflerin en klasik şekli "pasif direnme" ve "aktif direnme" şeklindeki tasniftir.

Zalim ve baskı rejimine karşı şiddete başvurmadan karşı koymanın en kolay yolu olan "pasif direnme" en fazla başvurulan bir direnme yöntemidir. Yöneticinin emirlerini açık olarak tutmamak, açlık grevi yapmak, resmi makam ve mansıpları kabul etmemek, inzivaya çekilmek, resmi kıyafet ve ritüelleri boykot etmek gibi eylemler pasif direnme örneklerinden bazılarıdır.

Aktif direnme ise; baskıcı ve dikta rejim ve yönetimlerini kuvvet ve gerekirse, şiddet yoluna başvurarak devirme hedefini güden bir direnme şeklidir. Genel olarak isyan ya da ihtilal hareketi olarak adlandırılan bu "saldırıcı ve yıkıcı direnme," pratik bakımdan bir "savaş" ve "kuvvet çatışması" niteliğini taşır. (Kapani, 1981: 313-4.) 
Direnme problemine bağlı olarak cevaplandırılması hiç de kolay olmayan çok sayıda soru vardır: Bask1 ve zulmün kriteri ve derecesi nedir? Bunu objektif olarak belirlemek mümkün müdür? Direnme gerçekten bir hak mıdır? Fertler bunu ne zaman meşru olarak kullanabilirler? Bu hak nereye kadar gider ve pratikte ne gibi şekiller alır? Bu soruların cevaplandırılması bu çalışmanın sınırlarını aşar. Biz burada direnme hakkının çok genel çerçevesini verip Nursi'nin baskıcı ve otoriter hükümetlere karşı politik tutumunu ele alacağız. Ancak ilk olarak İslamî doktrinde direnme ya da isyan hakkının boyut ve derecelerine kısaca göz atmakta fayda vardir.

\section{2. İslamî Doktrinde Direnme Hakkı}

İslâm siyasal doktrininde esas olan ilke ümmetin "kendilerinden olan" yönetime itaat etme ilkesidir. Bu sistemde direnme problemi esas değil talidir. Çünkü İslâmî anlayışa göre hem yönetenler, hem de yönetilenler şeriatın yüklediği belli mecburiyetlerle hem Allah'a hem de birbirlerine karşı sorumludurlar. Yönetilenlerin yönetenlere karşı birincil ve en önemli görevi itaat etmektir. İslâmi literatürün dini, hukukî ve siyasî yazılarında bu konu üzerindeki fikir birliği karşı çıkılamayacak kadar açıktır. Meşru otoriteye itaat etme gereği, sadece siyasî çıkar amacına yönelik değildir. Bu, aynı zamanda fikhın tanımladığı vahye ve akıl ve tecrübeye dayalı dini bir yükümlülüktür de. Meşru otoriteye itaatsizlik bir suç olduğu kadar bir günahtır.

Fakat ne yönetimin otoritesi ne de yönetilenlerin itaati sınırsız değildir. Her ikisi de bunları belirleyen, tanımlayan ve düzenleyen fikıh ve kelâm ilkelerine bağlıdır. Müslüman yönetici Şeriata uygun hareket etmek zorunda olduğundan kesinlikle bir despot olamaz. Genel olarak ümmetin uymakla yükümlü olduğu kanunlar düzenlendiği ve belirlendiği gibi yöneticilerin yönetim konusundaki tasarruf hakkı da kanunda saklanmış ve düzenlenmiştir. Başka bir otorite tarafından düzenlenen bu kanunlara o da en azından sıradan bir birey kadar uymak zorundadır. Burjuva yasama sisteminden farklı olarak, İslâmi sistemde yönetici başka bir otorite tarafından yapılmış kanunu değiştiremez; hatta ilke olarak onu izah etmek ve yorumlamak da onun görevi değildir. Onun görevi kanunu muhafaza etmek, adalet ve şefkat gibi ilkeler istikametinde icra etmektir. Ĕger bunları başaramazsa ve dahası bu kanunlara karsı gelirse o zaman bir yönetici olarak ümmetin itaat etmesini sağlayan Müslüman ve cemaatle anlaşmayı ve görevini ihlal ediyor demektir. Bu ise beraberinde belli sonuçlar doğurur. Diğerleri bir yana bu durum en başta tebaanın itaat görevini etkileyecektir.

İtaate lâyık olabilmek için devlet başkanının fakih ve kelamcılara göre iki şartı yerine getirmesi gerekir. Bunlardan biri meşru bir şekilde başa geçmeli ve ikincisi adaletle hükmetmelidir. Eğer hükümdarın idaresi gayri meşru ve icraatları 
adaletsiz ise karşılığında ümmetin kendisine itaat iddiasını kaybedecektir. (Rayyis, 1990: 141 vd; Şefik, 1991: 123; Canan, 1984: 254 vd; Mustafa, 1990: 183; Lewis, 1992: $141 \mathrm{vd}$ )

Müslüman bir hükümdara Müslüman tebaanın tam ve doğrudan itaat borcu vardır. Eğer bu hükümdar meşruiyetten yoksunsa veya meşruluğunu kaybederse ve adalet dışı icraatlarda bulunursa tebaanın itaat görevi düşer, hatta bunun yerini itaat etmeme görevi alabilir. İşte "direnme hakkı" denilen hak burada ortaya çıkar.

İslâm siyasal doktrinler tarihinde zalim ve baskıcı rejim ve yönetime karşı "direnme hakkı" ile ilgili genel olarak iki yaklaşıma şahit olmaktayız. Bunlardan birincisine "devrimci yaklaşım", ikincisine de "islahçı yaklaşım" dememiz mümkündür. Burada genel olarak müracaat edilen ve genellikle pejoratif anlamda kullanılan 'Siyasal İslam' kavramının doğru bir kavram olmadığını vurgulamak gerekir. İslam'ın bu tarz eklerle olumsuzlayıcı kontekstler içine geçirilmesi İslam'ın kendi asalet ve azametine aykırıdır diye düşünüyorum. 'Siyasal İslam' yerine 'Devrimci Yaklaşım' demenin daha uygun olduğu kanaatindeyim.

"Devrimci yaklaşım" zalim ve baskıcı yönetime karşı "isyan hakkı"nın meşru olduğu ve bu hakkın kullanılarak savaşmanın gerekliliği üzerinde durur ve Mü'minleri zalim yönetimle savaşmaya çağırır. "Islahçı Yaklaşım" ise fayda-zarar muhasebesi yaparak, savaşın sonucunda uğranılacak zararları dikkate alır ve zulme karş1 "sabır" etmenin, fakat bunun yanında tüm ıslah mekanizmalarını kullanarak irşat ve tebliğ faaliyetine girişmenin gerekliliğini vurgular.

İslamî gelenekte hem 'devrimci' hem de 'Islahçı' yaklaşım kendilerine İslâm'ın temel kaynakları olan Kur'an-1 Kerim ve hadis-i şerif'ten bol miktarda dayanak bulabilmektedir.

\section{Laik Otoriter Hükümetlerine Karşı Nursi'nin Tutumu: Müspet Hare- ket}

Nursi, siyasi literatürümüze 'istibdat' yılları olarak geçen dönemde gençlik yıllarını rejimle mücadele ederek geçirdi. Otuzlu yaşlarını 'meşru demokrasi'nin (meşrutiyet-i meşrua) kurulması ve kurumsallaştırılması mücadelesine adadı.

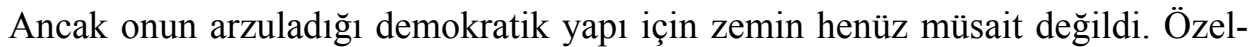
likle İttihatçılar'ın otoriter ve militarist tavrı Osmanlı demokrasi tecrübesini zaman zaman sekteye uğrattı. Cumhuriyet sonrası kurulan rejim ise hem aşırı din ve kültür-karşıtı bir ideolojiyle yüklü ve devrimci, hem de siyasi olarak otoriter ve baskıcıydı. Rejimin önderlerinin kendisiyle yeni ilkeler çerçevesinde uzlaşma ve beraber çalışma önerisine karşı Nursi'nin seçimi böyle bir yapının bir parçası olmak değil, bu yapıya karşı direnme yönünde olacaktı. Ancak bu direnme isyan anlamında 'aktif direnme' değil, huzur ve güven ortamını bozmadan muhalefet 
etme anlamında 'pasif direnme' olacaktı.

\section{4. 'Siyaset ve Şeytandan Allah'a Sığınırım'}

Nursi, laik, otoriter cumhuriyet hükümetlerine karşı neden isyan yolunu seçmedi? Nursi, laik otoriter cumhuriyet hükümetleri döneminde 'siyaset'e girmeyi isyan etme anlamında kullanır ve bunu şeytan'la eş tutar ve Allah'a sığınılacak bir hareket olarak görür (Nursi, 2004: 252, 258 vd). Siyasete girmenin şeytanla eş tutulması ilk nazarda paradoksal ve anlamsız gözükebilir, ancak işin mahiyetinin anlaşılmasıyla bu yaklaşımın son derece anlamlı, hikmetli, rasyonel bir iradi tercih olduğu görülür. Nursi, tek parti döneminde Cumhuriyet Halk Partisi içinde siyaset yapmayacağına ve bir muhalefet partisi de kurmayacağına göre, geriye kalan seçeneklerden birisi de isyan hareketlerine iştirak ederek siyasete müdahil olmaktı. Bu bağlamda Nursi, mevcut düzene isyan etmekten doğacak sonuçlardan Allah'a sığınırım demek istemektedir. Nitekim onun neden siyasete 'bulaşmadığını' ispat sadedinde ortaya koyduğu argümanlar bunu doğrular niteliktedir. Ona göre onun ve Nur Talebeleri'nin siyasete girmesini aşağıda inceleneceği gibi 'İhlas', 'Kur'an Hizmeti' ve 'Şefkat-i İmaniyye' engellemektedir.

\section{Devrimci Değil Islahçı Yol}

Nursi, "siyaset" konusunda genel strateji olarak "devrimci yaklaşımı"1 değil, "1slahçı yaklaşımı benimser. O, gerçekten tüm himmet, gayret ve enerjisini "1slah," "ikaz" ve "irşat" faaliyetine tahsis eder. Nursi'nin bu tip bir stratejiyi tercih etmesinin çeşitli nedenleri vardır. Bunlardan birincisi; içinde yaşadığı toplumun uzun savaşlar, dayatılan devrimler ve kültürel yabancılaştırma politikalarıyla kendi iradesi dişında cehalet ve gaflet içine itilmesidir. Bu nedenle toplum fertlerinin ahlaki önderliğe, "irşat" ve "1slah"a ihtiyacı vardır. Aslında bu toplum bin yıldır İslâm'ın bayraktarlığını yapan ve yerkürenin önemli bir bölümünde İla-i Kelimetullah görevini ifa eden bir ecdadın torunlarıdır. "Cibilliyeten" de Müslüman'dır. Nursi'ye göre bu toplum zamanı geldiğinde yine dedeleri gibi İslam ve Kur'an için hayatlarını feda edip şehit olmaya hazırdır. Bu nedenle çeşitli nedenlerden dolayı karşı cephede yer almak durumunda kalan bu insanlardan bazılarının olumsuz etkileneceği siyasi operasyonlara girişmek doğru değildir. Nursî ahlaki önderlik sürecine çok önem verir ve Kuranî hakikatlerin maddi ve manevi hiçbir şeye alet edilmeksizin bu topluma yaşanarak gösterilmesinin gerekliliğine inanır. Lüzumlu olan toplumla savaşmak değil, şefkatli bir dille iletişim kurmaktır.

\section{Kur'an Hizmeti Hiçbir Şeye Alet Yapılmamalıdır}

Nursi, mevcut siyasi yapıya "isyan hakkı"nın kullanılmasının bu zamanda doğru olmamasını toplumun içinde bulunduğu ortama bağlar. Ona göre uzun zamandan beri Batı'dan kaynaklanan materyalist ve ateist cereyanlar ve fikirlerle 
toplum (özellikle aydın kesimi) geniş ölçüde manevi ve ruhi özünden uzaklaştırılmış, kendi orijinal doğasına yabancılaştırılmış, iman ve ahlâkında büyük tahribatlar yapılmıştır. Dolayısıyla toplum fertleri Kur'an hakikatlerini anlamakta zorluk çekmektedirler. Bu bakımdan topluma daha şefkatli yaklaşılmalı ve yaraları özenle tedavi edilmelidir. Buna göre acilen yapılması gereken şey; iman ve Kur'an hakikatlerini her türlü menfaat ve "garaz"dan arınmış olarak sunmak ve toplumla samimiyet ve sadakat zemininde buluşmaktır. Bu çerçevede iman ve Kur'an hizmetini maddi ve manevi hiçbir şeye âlet ve basamak yapmamak, böyle bir izlenimin doğmasına bile izin vermemektir. Aksi durumda ahlâki ve imanî açıdan yozlaşan ve her şeyi belli menfaatlere basamak yapıldığını gören toplum fertleri iman ve Kur'an hizmetinin de maddi ve siyasi hedeflere âlet ve basamak yapıldığını sanacak ve Kur'an'la buluşmak istemeyecektir. Bu ise toplumun İslamî gelenekten iyice uzaklaşıp giderek sekülerleşmesine neden olacaktır. Böyle bir ortamda Nursi'ye göre dindarlara düşen şiddete başvurup çok sayıda masumun zarar görmesine neden olmak değil, hatta onların içindeki zalimlere bile beddua etmemektir. Çünkü toplumda zalim-mazlum, suçlu-masum bir arada yaşamakta; zalime yönelecek şiddetten zalimlerden fazla masumlar zarar görecektir. Nursi bu stratejisinin altını çok net çizer:

"Benim ve Risâle-i Nur'un mesleğinin esası ve otuz seneden beri bir düsturu... olan şefkat itibariyle bir masuma zarar gelmemek için bana zulmeden canilere değil ilişmek, belki beddua ile de mukabele edemiyorum. Hatta en şiddetli bir garaz ile bana zulmeden bazı fâsık, belki dinsiz zalimlere hiddet ettiğim halde değil maddi (mukabele) belki beddua ile mukabeleden beni o şefkat men ediyor. Çünkü o zalim gaddarın peder ve validesi gibi ihtiyar biçarelere veya evladı gibi masumlara maddi zarar gelmemek için o dört beş masumların hatırına binaen o zalim gaddara ilişmiyorum, bazan da hakkımı helal ediyorum." (Nursi, 1994: 372-3)

Nursi'nin tüm çabası sanki “Fetret Devri” niteliğine sahip olan bir çağın insanlarına Kur'an hakikatlerini doğrudan ve perdesiz sunabilmektir. Bu takdimi engelleyecek her türlü davranış ve plandan şiddetle kaçınmaktır:

"Amma Kur'an ve iman hizmeti ne için (siyasetten) men ediyor?" dersen; ben de derim ki, "Hakaik-1 imaniyye ve Kur'aniye birer elmas hükmünde olduğu halde, siyaset ile alude olsa idim, elimdeki o elmaslar iğfal olunabilen (kandırılabilen) avam tarafından 'Acaba taraftar kazanmak için bir propaganda-ı siyaset değil mi?' diye düşünürler. Bu elmaslara adi şişeler nazarıyla bakabilirler. $\mathrm{O}$ halde ben o siyasete temas etmekle o elmaslara zulmederim ve (bu davranışım) kıymetlerini tenzil etmek hükmüne geçer. (Nursi, 1959: 38)

Nursi'ye göre toplumun içinde bulunduğu durumdan kurtarılabilmesi için iki yol vardır; bunlardan biri, toplumun sarhoş kesimini "siyaset topuzu" ile kafalarına vura vura ayıltmak; ikincisi ise "bir nur göstererek insanlara ahlaki önderlik yapmaktır. 
"Ben bakıyorum ki," der, "yirmiye karşı seksen adam elinde topuz tutuyor. Hâlbuki o biçare ve mütehayyir olan seksene karşı hakkıyla nur gösterilmiyor. Gösterilse de; bir elinde hem sopa hem nur olduğu için emniyetsiz oluyor. Mütehayyir adam, "Acaba beni nurla celb edip topuzla dövmek mi istiyor?" diye telâş eder. Hem de bazen arızalarla topuz kırıldığı vakit nur dahi uçar veya söner." (Nursi, 1985a: 51) Nursi, “iki eli olduğunu, yüz eli de olsa" "hepsiyle nur tutacağını" topuz tutmayacağını, çünkü bu zamanda topuza değil, nura ihtiyacın olduğunu israrla vurgular.

\section{7. İsyan Hakkını Kullanmaya Engel Olan Bir Diğer Unsur: Şefkat}

Hayatı ve düşünce sisteminden anlaşıldığına göre Nursi'nin plan, karar ve eylemleri "şefkat" duygusunun etkisi altında şekillenmektedir. Genel hareket stratejisini belirlerken şefkatin ne ölçüde etkili olduğunu aşağıdaki satırlardan görmek mümkündür:

Binler haysiyet ve şerefimi bu vatandaki biçarelerin istirahatı ve onlardan belâların define (kalkmasına) feda etmek için (Cenâb-1 Hak) bana bir halet-i ruhiyyeyi ihsan eylemiş ki; ben de onların (zalim yöneticilerin) yaptığı ve niyetinde bulundukları tahkirat (aşağılama) ve ihanetlerine karşı tahammüle karar vermişim. Bu milletin asayişine, hususan masum çocukların ve muhterem ihtiyarların ve biçare hastaların ve fakirlerin dünyevî istirahatlarına ve uhrevî saadetlerine binler hayatımı ve binler şerefimi feda etmeye hazırım. (Nursi, 1959: 29)

Nursi, kafasındaki siyasi düzeni kurmak için şiddete başvurarak mevcut iktidara başkaldırması durumunda masum insanların uğrayacağı felaketlerin bilincindedir:

Şefkat-i vicdan, hakikat bizi siyasetten men ediyor. Çünkü tokada müstehak dinsiz münafiklar onda iki ise, onlara müteallik yedi sekiz masum, biçare çoluk çocuk, zaif, hasta ve ihtiyarlar var. Belâ ve musibet gelse masumlar belâya düşecekler. Belki o iki münafik dinsiz daha az zarar görecek. (Nursi, 1985b: 155)

Dikkat edileceği gibi, siyasetle amaca ulaşılmasının seçilmesi durumunda hem sonucun alınması kesin olmayacak, hem de harekat esnasında karşı taraftan zarar görenler yine masumlar olacaktır. Esas zarar görmesi gereken bozguncular ve zalimler ise ya hiç zarar görmeyecek ya da çok az bir zararla kurtulacaklardır.

Öte yandan bu dönemde otoriter rejimler son derece gelişmiş silah teknolojilerine de sahip olduklarından gerçekleştirecekleri yıkım ve zararın boyutu eski dönemlere göre çok daha şiddetli ve sert olacaktır. Emperyalist Batı uygarlı̆̆ının ürettiği insan tipi öyle bencil, narsist, sadist, 1rkçı, militarist ve zalimdir ki, bunlar iktidarlarını ellerlinden kaçırmamak için dünyayı ateşe verebilirler:

...(içinde yaşadığımız) asırda gaddar medeniyetten neşet eden hodgamlık ve asabiyet-i unsuriye (1rkçılık damarı) ve umumi harpten gelen istibdad-1 askeriye (militarist baskı) ve dalaletten çıkan merhametsizlik cihetinde öyle bir 
eşedd-i zulüm ve eşedd-i istibdadat meydan almış ki, ehl-i hak hakkını kuvvet-i maddiye (güç kullanarak) ile müdafaa etse ya eşedd-i zulüm ile tarafgirlik bahanesiyle çok biçareleri yakacak... çünkü mezkur hissiyatla hareket ve taarruz eden insanlar bir iki adamın hatasıyla yirmi otuz adamı adi bahanelerle vurur, perişan eder. (Nursi, 1994: 292)

Emperyalist, militarist ve vandalist duygular ve eğilimlerle hareket eden zalimlere karş1 Müslümanlar nasıl davranmalıdır? "Mukabele-i bil'misil” zalim ilkesiyle onlar gibi vandalist duygularla masum ve mazlumları da yakıp yıkmalı mı? Yoksa bu konuda ehl-i hakkı bağlayan, sinırlayan engelleri dikkate alarak daha değişik strateji mi izlemelidir? Nursi bu konuda şunları söyler:

Eğer ehl-i hak, adalet yolunda yalnız vuranı vursa, otuz zayiata mukabil yalnız (ca) biri kazanır (ve böylece) mağlup vaziyetinde kalır. Eğer mukabele-i bil'misil kaide-i zalimanesiyle (ayniyla karşlık verme kaidesi) o ehl-i hak dahi bir iki (kişi)nin hatasıyla yirmi otuz biçareleri ezse, o vakit hak namına dehşetli bir haksızlık ederler. İşte Kur'an'in emriyle gayet şiddetle ve nefretle siyasetten ve idareye karışmaktan kaçındığımızın hakiki hikmeti ve sebebi budur. Yoksa bizde öyle bir hak kuvveti var ki, hakkımızı tam müdafaa edebilirdik... (Nursi, 1994: 292.)

Yukarıdaki satırlardan da anlaşılacağı gibi, Nursi ilginç bir hesap tekniğiyle menfi hareketin sonunda "ehl-i hakkın" aleyhine sonuçlanacağı neticesine varır. Karşı cephede olan zalimler gibi hareket edilip, masum-zalim farkı gözetmeden "vurulsa" bu defa kesinlikle İslâmî olmayan zalim bir fiilin içine girilmiş olur. Oysa masum ve mazlumun hakkı İslâm' da garanti altına alınmıştır.

\section{Müsbet Hareket}

Nursi, kendisine ve kendisini izleyenlere her türlü bask1 ve zulüm yapılsa, en temel haklarından bile mahrum bırakılmaya çalışılsa da hiçbir zaman yıkıcı, bölücü ve toplumsal huzuru bozucu bir eğilime sahip olmamıştır. Nursi, yapılan zulüm ve haksızlıkları eleştirmekle birlikte toplumsal huzur ve barış için yapıcı olmayı ve müspet hareket etmeyi seçmiştir. S1k sık vurguladığı müspet hareketten o, bir taraftan her türlü maddi ve manevi çıkardan arınmış bir ahlaki önderliği, diğer taraftan toplumun çeşitli kesimlerinin birbiriyle entegre olmasını ve bütünleşmesini, dayanışma ve barış içinde yaşamasını kast etmektedir. Bu, en ciddi kırılma ve gerilim alanları olan dindar ve seküler kesim arasında yapıcı bir diyalogu, çeşitli etnik guruplar arasında kardeşliği, farklı mezheplerin birbirini hoşgörmesi ve kabullenmesini esas almaktadır. Nursi toplumsal huzur ve bütünleşmeye katkısı konusunda kendisinden o kadar emindir ki kendisi ve talebelerinin birer 'manevi zabıta' gibi ülke genelinde faaliyet gösterdiğini ve asayişe hizmet ettiklerini ifade eder.

Sonuç olarak Nursi laik dikta hükümetleri genel olarak dini kültüre yıkıcı ve devrimci darbeler vurması ve özel olarak kendisi ve talebelerini sürekli baskı 
ve zulüm altında bulundurmasına rağmen hiçbir zaman şiddete başvurmamış ve müspet hareket etmekten vazgeçmemiştir. Yazdığ kitaplar ve yüz binleri bulan izleyenleriyle hep toplumsal huzur ve barışın güvencesi olmaya çalışmıştır.

\section{Dindar Demokratların Hükümetlerine Karşı Müspet Hareket ve Destek}

Demokrat Parti gibi bir partinin iktidara gelmesi şüphesiz Nursi durumunda olan her insan için heyecan ve umut verici bir olaydı. Realist ve gerçekçi olan Nursi, Demokrat Parti'nin iktidarı devralmasını önemsemiş ve tebrik edilmesi gereken bir olay olarak değerlendirmiştir.

Nursi'nin Demokrat Parti iktidarını nasıl desteklediğine geçmeden önce Nursi-sonrası dönemde Nursi izleyicilerinin kendi aralarında ihtilafa düştügü̈ 'Demokratlar' ya da 'Ahrarlar' kavramından Nursi'nin neyi kast ettiği, hangi vasıflara sahip bulunan siyasilerin bu kategori içerisine girebileceğini belirlememiz gerekir. Günümüzde 'ahrarlar' denilerek siyasi tercihe konu edilen siyasilerin, Nursi'nin yazılarındaki özel nitelikleri taşıyıp taşımadıklarının belirlenmesinin kafa karışıklığının önlenmesi için gerekli olduğunu düşünüyorum.

\section{0. 'Dindar Demokratlar'}

Bir kere Nursi Demokratları nitelerken hemen tüm nitelemelerinde 'Dindar Demokratlar', ya da 'Hamiyetkâr Dindar Demokratlar' nitelemesi yapar. Demokrat Parti'nin iktidara gelmesinden sonra kaleme aldığı İkinci EmirdağıLahikası'na kısaca göz atıldığında Nursi’nin aşağıdaki nitelemeleri yaptığını görürüz: 'dindar ve dine hürmetkâr Demokrat Parti'; 'Risale-i Nur'un resmen serbestiyetini dindar Demokratlar ilân etmelidirler'; 'dindar Demokratlara iltihak etmeye mecbur olur'; 'Demokrat dindar milletvekillerine bir hakikati ihtar'; 'dindar hürriyetperverlere beyân etmekle iktifa ediyorum'; 'hürriyetperver dindar Demokratlara'; 'dindar hürriyetperverler'; 'Mâdem Cenâb-1 Hak, bu tehlikeli zamanda bir kısım hakîki dindarların başa geçmesine yol açmış'... Bazen de Nursi doğrudan isim zikrederek o ismi dindarlıkla niteler: 'İslâmiyet' in bir kahramanı olan Adnan Menderes gibi dindarlara beyân ediyorum' (Nursi, 2004: 12 vd).

Nursi, Demokrat Parti'nin sadece dindarlardan müteşekkil bir siyasi yapı olmadığının doğal olarak bilincindedir. Hatta bizzat kendisi o partinin içinde masonların, komünistlerin ve zındıkların da olduğunu ifade etmektedir. Ancak ona göre partinin genel havası dindardır ya da dine hürmetkârdır. Nitekim Nursi, aşağıda izah edileceği gibi Demokrat Parti'den beklediği icraatları sıralarken mason ya da dinsiz kesimin bu icraatları engelleme yoluna gidebileceğini, dindar demokratların bunun bilincinde olması gerektiğini ihtar eder.

\section{Dindar Demokratlardan Beklenen İcraatlar}


Nursi'nin dindar demokratlardan öncelikli olarak beklediği bazı icraatlar vardır. Bunlar; iç ve dış politikaların 'ittihad-1 İslam'a yönelik belirlenmesi; Kur'an hakikatlerine dayanılması, yani suçun bireyselliğinin esas bir ilke olarak kabul edilip uygulanması, ulusçu ve 1rkçı uygulamalardan kaçınılması ve İslam kardeşliğinin güçlendirilmesi; özellikle mahkûmları dikkate alan bir adil af kanununun çıkartılması; dindarların irşat ve tebliğ faaliyetini engelleyen yasaların kaldırılmas1 ve fikri hürriyetin sağlanması; din dersinin okullarda zorunlu ders olarak konulması; İslami şeairin ihyası; bürokratik tahakkümün önlenmesi ve yönetimin toplumun hizmetkarı olduğunun benimsenmesi; Risale-i Nurların neşri ve okunmasının serbest bırakılması; Ayasofya'nın tekrar camiye çevrilmesi; ehli ilim ve ehli- tarikatın üzerindeki baskıların kaldırılması, Doğu illerinde üniversitelerin açılması vs.

Bunlardan özellikle ittihad-1 İslam'a yönelik icraatlara Nursi sık sık atıfta bulunur:

Şimdi milletin arzusuyla şeair-i İslâmiyeninserbestiyetine vesile olan Demokratlar, hem mevkilerini muhafaza, hem vatan ve milletini memnun etmenin çare-i yegânesi; ittihad-1 İslâm cereyanını kendine nokta-i istinad yapmaktır. Eski zamanda İngiliz, Fransız, Amerika siyasetleri ve menfaatleri buna muarız olmakla mani olurdular. Şimdi menfaatleri ve siyasetleri buna muarız değil; belki muhtaçtırlar. Çünkü komünistlik, masonluk, zındıklık, dinsizlik; doğrudan doğruya anarşistliği intaç ediyor. Ve bu dehşetli tahrib edicilere karşı, ancak ve ancak hakîkat-1 Kur'âniye etrafında ittihad-1 İslâm dayanabilir. Ve beşeri bu tehlikeden kurtarmağa vesile olduğu gibi, bu vatanı istila-yı ecanibden ve bu milleti anarşilikten kurtaracak yalnız odur. Ve bu hakîkata binaen Demokratlar bütün kuvvetleriyle bu hakîkata istinad edip komünist ve masonluk cereyanına karşı vaziyet almaları bir hacet-i zarurîdir. (Nursi, 2004: 47)

Nursi, ulusçu ve rrkçı fikir ve politikaların İslam ümmeti aleyhinde işlenmiş en büyük cinayet olduğunu, Müslümanlar arasındaki muhabbet ve dayanışmayı paramparça ettiğini oysa demokratlığın içeriğinde kardeşlik bulunduğunu dolaysıyla Millet Partisi gibi partilerin bu açıdan Demokrat Parti'ye iltihak etmesi gerektiğini söyler.

Nursi İttihad-1 İslam konusunda İslam dünyasında Nur Talebeleri'ne en ciddi müttefikin İhvan-1 Müslimin olduğunu vurgular. Halepli bir ihvan üyesinin Risaleleri tebrik etmesi üzerine yazdığ 1 bir mektupta Nursi, İttihad-1 İslamı Arabistan'da İhvan'in, Anadolu'da da Nur Talebelerinin gerçekleştireceğini söyler. (Nursi, 2004, s.28)

Nursi'nin mektuplarından çıkartabileceğimiz başka önemli bir kriter kesinlikle dinin siyasete alet edilmemesi kriteridir. Nursi kendi zamanında İttihad-1 İslam Partisi, Halk Partisi, Millet Partisi ve Demokrat Parti olmak üzere dört partinin bulunduğunu, bunlardan Demokrat Parti'nin iktidara gelip diğer partilerin gelme- 
mesi gerektiğini söyler. Nursi’ye göre İttihad-1 İslam Partisi'nin şimdilik siyasette aktif olmaması gerektiğinin nedeni toplumun ahlak-1 İslamiyesinin bozulmuş olmasından dolayı siyasilerin ister istemez dini siyasete alet etmek zorunda kalacak olmalarıdır. (Nursi, 2004, s.143; Vapurlu, 2011 )

Burada bizim için önemli olan Nursi'nin devreye soktuğu temel kıriterdir. Ona göre dinin siyasete kesinlikle alet edilmemesi gerekir. Bunun anlamı dini argümanların sadece propaganda malzemesi olarak kullanılması, ama icraatta ihmal edilmesi, yani siyasetin dine alet edilmesinden vazgeçilmesidir. Şayet iktidara aday olan bir parti siyasi propaganda malzemesi olarak dini argümanlara en asgari düzeyde müracaat eder, fakat icraatında Nursi'nin yukarıda sıraladığı isteklerini yerine getirmeye çalışırsa bunların ekseriyetinin dindar olmasının iktidara gelmeleri için bir engel olmadığıdır. Yani İttihad-ı İslam Partisi'nin (ve benzerlerinin) şimdilik iktidara gelmemesi, dindar olmalarından dolayı değil, dini siyasete alet etme zorunda kalmalarından dolayıdır. Buna göre dini siyasete alet eden parti ne tür parti olursa olsun desteklenmemeli ve iktidara gelmemelidir.

\section{Dindar Demokratların İktidarına Karşı Müspet Hareket ve Destek}

Nursi, başta dua olmak üzere dindar demokratların iktidarını destekleme eğilimindedir. Bunu Celal Bayar, Cumhurbaşkanı olur olmaz ona yazdığ 1 tebrik telgrafinda ortaya koyar:

'Zâtınızı tebrik ederiz. Cenâb-1 Hak sizi İslâmiyet ve vatan ve millet hizmetinde muvaffak eylesin.'

Nursi, demokratların iktidara gelmesini kendisi ve izleyicileri için de son derece faydalı bir gelişme olarak değerlendirir. Reis-i Cumhur Celâl Bayar ve Hey’et-i Vükelâsına diye kaleme aldığı bir mektupta: 'Biz Nur Talebeleri yirmi senedir emsalsiz bir tâzib ve işkencelere hedef olmuşuz. Sabrettik. TâCenâb-1 Hak sizi imdadımıza gönderdi' (Nursi, 2004: 12) diyerek demokratların iktidarının da tüm inananlarla beraber kendileri için de ne kadar yararlı olduğunu ifade eder.

Nursi'nin demokratların iktidarını desteklemesi onların sadece Nur hareketine serbestlik tanıması açısından değildir. Demokratlar Nursi'nin paylaştığı çok sayıda değeri paylaşmakta, mücadele ettiği düşmanlarla mücadele etmektedir.

Nursi, 'demokratlara büyük bir hakikatı ihtar', (Nursi, 2004: 182) başlığı altında kaleme aldığı bir değerlendirmede dindar demokratlarla paylaştığı değerleri ve ortak mücadele alanlarını ortaya koyar. Nursi'ye göre bu zamanda Kur'an ve ülke için üç zararlı cereyan vardır. Bu cereyanlar toplumun değerleri ve birlik bütünlüğü için zararlıdırlar. Nursi’ye göre bu cereyanlardan birinci cereyan komünizm ve dinsizlik cereyanıdır, bu cereyan toplumun yüzde otuz- kırkına zarar verebilir. İkinci cereyan bir 'ifsat komitesi'dir ki bu komite Türkiye'deki Müslümanlarla 
diğer İslam dünyasındakilerin arasındaki ilişkiyi kesmek için çalışmakta ve bunun için toplumu dinsizleştirmeye gayret göstermektedir. Nursi'ye göre bu komitenin etki alanı ise toplumun yüzde on-yirmisi kadardır. Üçüncü cereyan ise seküler bir kısım siyasilerdir ki toplumu batılılaştırmak ve Hıristiyanlara benzeterek bir nevi Protestanlık mezhebini Müslümanlar içinde yerleştirmeye çalışmaktadırlar. Nursi, bu cereyanın olumsuz etkisinin sinırlı olduğunu, bunların ancak toplumun yüzde, belki binde birini etkileyebileceğini söyler.

Nursi, kendisi ve talebelerinin ilk iki cereyana karşı daima Kur'ân hakikatlerini muhafazaya çalıştıklarını, mümkün olduğu kadar dünyaya ve siyasete bakmamaya gayret gösterdiklerini, ancak demokratların iktidara gelmesiyle mecburen siyaset ve dünya işlerine bakmaya başladıklarını söyler. Dindar Demokratların ilk iki cereyana zaten muhalif olduklarını, dolaysıyla o cereyanlara karşı demokratlarla müştereken mücadele edebileceklerini vurgular. Demokratların içinde dindar olmayan bir kısım kişilerin batılılaşma politikasıyla üçüncü cereyana yardım ettiklerini oysa bu çabanın boşuna olduğunu, bunlar yapsa yapsa ancak toplumun binde birini Protestan gibi yapabileceklerini çünkü, İngilizlerin iki yüz senede tahakküm ettiği iki yüz milyon Müslüman'dan iki yüz kişiyi Protestanlığa çeviremediğini hatırlatır.

Nursi, Demokrat Parti'nin ilk iki cereyanın engellenmesi konusunda çaba sarf etmesini olumlu karşılar ve bu çabanın vatana ve İslâmiyet'e büyük bir fayda sağlayacağını vurgular. Bu nedenle kendilerinin de Demokratları iktidarda muhafaza etmeye Kur'ân menfaatine mecbur olduğunu ifade eder. Nursi gerçekçi olarak demokratlardan beklentisini asgari düzeyde tutar ve onların hangi ağır şartların altında faaliyet gösterdiğinin bilinci içerisindedir. $\mathrm{O}$, demokratlardan çok büyük hayırlar beklemek değil, belki onların iki cereyana karşı muarız olmalarından, onları desteklemek durumunda olduklarını ifade eder. Nursi, demokratların içinde bulunan az sayıda batılılaşma yanlılarının politikalarını benimsememekle birlikte diğerlerinin politikalarını desteklemek durumunda olduklarını vurgular. Batılılaşma yanlılarının dine zarar verdiklerinin farkında olduklarını, ancak bunu vücudun parçalanması yerine bir parmağın kesilmesine razı olmak gibi gördüklerini söyler. Bu nedenle Nursi, Demokrat Parti'nin hükümetinin lehinde dindarları yardıma davet eder.

Ölümüne yakın talebelerine vasiyetinde yine hem müspet hareket etmelerini hem de Demokrat Parti iktidarını desteklemelerini söyler:

'Kardeşlerim! Hastalığım pek şiddetli, belki pek yakında öleceğim veyahut bütün bütün konuşmaktan -ba'zanmen'olduğum gibi- men' edileceğim. Onun için benim Nur âhiret kardeşlerim, ehvenüşşer deyip ba'zıbiçâreyanlışçıların hatalarına hücum etmesinler. Dâima müspet hareket etsinler. Menfî hareket vazifemiz değil. Çünkü dâhilde hareket menfîce olmaz. Mâdem siyasetçilerin bir 
kısmı Risâle-i Nur'a zarar vermiyor, az müsaadekârdır; “ehvenüşşer” olarak bakınız. Daha azamüşşerden kurtulmak için; onlara zararınız dokunmasın, onlara fâideniz dokunsun.' (Nursi, 2004: 216-7)

\section{Sonuç}

Bu çalışmada ulaşılan sonuçları aşağıdaki şekilde özetlememiz mümkündür:

1- Siyasal doktrinde zalim ve otoriter yönetimlere karşı 'direnme hakkı' adı altında biri şiddet ve silah kullanmayı içeren, diğeri pasif direnme olarak şiddete başvurmadan muhalefet etmeyi ihtiva eden iki çeşit direnme vardır.

2- İslamî doktrinde de zulüm ve adaletsiz yönetimlere karşı biri 'devrimci' ve diğeri '1slahçı' yol olmak üzere iki yaklaşım vardır. Devrimci yaklaşım isyan ve savaşı öngörürken, 1slahçı yaklaşım sabrı, irşat ve nasihati öngörür.

3- Nursi, laik otoriter hükümetlere karşı muhalefetini şiddete başvurmadan 'müspet hareket' ilkesini esas almış, şiddete başvurmayı reddetmiştir. Dindar Demokratların hükümetlerine karşı ise hem 'müspet hareketi' hem de onların iktidarda kalmaları için yoğun destek ve dua etme yolunu seçmiştir.

4- Nursi, siyasal tercih kriteri olarak demokratların sadece demokratlı̆̆ını esas almamış, aynı zamanda dindar olmalarını da dikkate almıştır.

5- Nursi demokratların iktidarından; Müslümanlar arasında kardeşliğin esas alınması (ittihad-1 İslam), her türlü baskının kaldırılarak fikir, düşünce ve ibadet hürriyetinin sağlanması, din derslerinin okullarda zorunlu ders yapılması, hukukta suçun ferdiliği ilkesinin kabul edilip uygulanması, Risale-i Nur ve diğer dini neşriyatın serbestleşmesi, Ayasofya'nın ibadete açılması, komünizm, dinsizlik ve batılılaşma cereyanlarıyla mücadele edilmesi gibi icraatlar bekler.

6- Sonuç olarak Nursi, dindar iktidarların yapabilecekleri icraatların sınırı hakkında gerçekçi biri olarak onlardan asgari hayır bekler. Öğrencileri ve kendisini izleyenlere onları yıkıcı eleştiri ile sarsmamalarını, tersine onlara yardımcı olmaya çalışmalarını tavsiye eder.

\section{Kaynaklar}

Vapurlu, A. (2004). Bediüzzaman Said Nursi'den İctimâ̂-Siyasî Tespitler. İstanbul: Yeni Asya.

Nursi, B. S. (2004). Emirdă̆ Lahikası II. İstanbul: Sözler Yayınevi.

Nursî, B. S. (1959). Emirdă̆ Lahikası I. İstanbul: Sinan Matbaası.

Nursî, B. S. (1994). Şualar. İstanbul: Envar Neşriyat.

Nursî, B. S. (1985a). Mektubat. İstanbul: Sinan Matbaası.

Nursî, B. S. (1985b). Kastamonu Lahikası. Ankara: Doğu Ltd. Şirketi Matbaası. 
Lewis, B. (1992). İslâm 'ın Siyasal Dili. Çev. F. Taşar. İstanbul: Rey Yayınları.

Duran, B. (1995). “'Direnme Hakkı” ve Bediüzzaman'ın "Siyaset”e Yaklaşımı'. Köprü Dergisi. sayı: 50.

Şirvani, H. H. (1965). Siyasi Düşünce ve İdare. Çev. K. Kuşçu. Ankara: Nur Yayınları.

Canan, İ. (1984). İslâm Işı̆̆ında Anarşi. İstanbul: Cihan Yayınları.

Kapani, M. (1981). Kamu Hürriyetleri. Ankara: Ankara Ün. Hukuk Fak. Yay.

Şefik, M. (1991). Çağdaş İslâm Düşüncesi. Çev. E. Pınarbaşı. İstanbul: Dünya Yayınc1lik.

Mustafa, N. A. (1990). İslâm Siyasi Düşüncesinde Muhalefet. Çev. V. Akyüz. İstanbul: İz Yayıncilik.

Rayyis, Z. (1990). İslâm'da Siyasi Düşünce Tarihi. Çev. A. Sarıkaya. İstanbul: Nehir Yayınları. 